\title{
The Study on Association of Calcium Channel SNPs with Adverse Drug Reaction of Calcium Channel Blocker in Korean
}

\author{
Myeon Woo Chung, Syrie Bang, Sun Kyung Jin, Sun Wook Woo, Yoon Jung Lee, \\ Young Sik KIM ${ }^{1}$, Jong Keuk LeE ${ }^{1}$, Sung Ho LeE ${ }^{2}$, Hye Joo ChUNG*, and Jaesook RoH* \\ National Institute of Toxicological Research, Korea Food and Drug Administration, Seoul, 122-704, Korea \\ ${ }^{1}$ College of Medicine, University of Ulsan, Seoul, 138-736, Korea \\ ${ }^{2}$ Department of Thoracic \& Cardiovascular Surgery, Anam Hospital, Korea University, Seoul 122-704, Korea
}

(Received 20 June 2007; Accepted 17 August 2007)

\begin{abstract}
Rapid advances in pharmacogenomic research have provided important information to improve drug selection, to maximize drug efficacy, and to minimize drug adverse reaction. The SNPs that are the most abundant type of genetic variants have been proven as valid biomarkers to give information on the prediction of pharmacokinetic/pharmacodynamic properties of drugs based on genotype. In order to elucidate a correlation between SNPs of calcium channel encoding gene and adverse reactions of calcium channel blockers, we investigated SNPs in CACNA1C gene known as a binding site of calcium channel blocker. 96 patients with hypertension who had taken or are taking an antihypertensive drug, 1,4-dihydropyridine (DHP) were included for analysis. These patients were composed of 47 patients with adverse drug reactions (ADR) such as edema from calcium channel blockers and 49 patients without ADR as a control group. The exons encoding the drug binding sites were amplified by PCR using specific primers, and SNPs were analyzed by direct sequencing. We found that there was no SNP in the exons encoding DHP binding site, but four novel SNPs in the exon-intron junction region. However, four novel SNPs were not associated with the ADR of calcium channel blockers. In conclusion, this study showed that ADR from calcium channel blockers may not be caused by SNPs of the binding sites of calcium channel blockers in CACNA1C gene.
\end{abstract}

Key words $\square$ Calcium channel blocker, Adverse Drug Reaction, SNP, CACNA1C gene, Korean

\section{INTRODUCTION}

Rapid advances in pharmacogenomic/pharmacogenetic research have identified many opportunities for the drug development and personalized treatments for subsets of patients defined as a specific genotype (Lesko and Woodcock, 2004). The constant findings of genetic variants rise interests for the development of personalized treatments and partially, it has been applied in a clinical practice (Marsh and McLeod, 2006). Actually, genotyping tests have been carried out in many clinical trials during drug development and the pharmacogenetic information relevant to the drug has been provided to physicians through Physicians Desk Reference in the Unite States. Recently U.S. Food and Drug Administration have recommended industries to submit pharmacogenetic data for New

\section{*Corresponding author}

Tel: +82-2-380-1807(11), Fax: +82-2-380-1814

E-mail: rohjs@kfda.go.kr, hjchung@kfda.go.kr
Drug Application (Little, 2005).

According to age, sex, disease status and so on, there are inter-individual different responses to medicine (Mango et al., 2005). And the genetic variations of metabolic enzyme, transporter, receptor and drug target are also one of the reasons to show inter-individual different response. Therefore these genetic variations can provide an important clue that explains the difference in drug efficacy and adverse drug reaction (ADR), and be an important biomarker to predict the different response to the drug (Solus et al., 2004).

Hypertension has been listed as one of the major disease in Korean. Calcium channel blockers (CCBs) were the most commonly prescribed for hypertensive patients. However, it is reported that CCBs have produced adverse events such as edema in $15 \sim 39 \%$ of the patients and that CCBs have been withdrawn in 10\% of Korean patients due to ADR (Kim et al., 2000).

There are three types of CCBs; phenyl alkylamines, benz (othi)azepines and 1,4-DHPs. Among them, 1,4-DHPs have been the most widely used (De Leeuw and Birkenhager, 2002; 
Muntwyler and Follath, 2001). 1,4-DHPs bind the specific sites of cardiac and smooth muscle and prevent $\mathrm{Ca}$ influx into the cells through L-type Ca channel (Barone et al., 1997). Amlodipine and cilnidipine have been known as the third-generation of 1,4-DHP and long lasting antihypertensive effect(Furukawa et al., 1997; Mason et al., 2003; Uneyama et al., 1997).

In order to select the candidate gene to identify the association of adverse reaction from $\mathrm{CCBs}$ and genetic polymorphisms, we analyzed the type and frequency of adverse reaction caused by CCBs. Because common ADRs such as edema and flush induced by CCBs could be resulted from the excessive vessel dilation, we investigated the L-type calcium channel containing the binding site of 1,4-DHP. According to the previous study, at least five classes of voltage-gated calcium channels have been identified: L, N, P/Q, R and T type (Ertel et al., 2000). It has been reported that 1,4-DHP binds the L-type calcium channel (Birnbaumer et al., 1994; Hofmann et al., 1994). L-Type channel is the predominant type in heart and vascular tissue and plays a central role in cardiac and smooth muscle excitation-contraction coupling (Birnbaumer et al., 1994). LType calcium channel is a complex of the main, pore-forming subunit alpha-1 and four additional subunits: alpha-2, delta, beta and gamma (Uneyama et al., 1997). Among the subtype of alpha-1, 1,4-DHP binds to the alpha 1C subunits (CACNA1C) with high affinity (Birnbaumer et al., 1994; Hofmann et al., 1994). The alpha 1C subunits consist of four homologous repeats (I IV), each of which is composed of six putative transmembrane segments (S1-S6) (Liu et al., 2000). According to the previous reports, the major binding site of 1,4-DHP is the S5 and S6 transmembrane segment of repeat III, the S6 transmembrane segment of repeat IV, the S5 -S6 linkers of repeat III and IV at the CACNA1C (Hockerman et al., 1997; Regulla et al., 1991; Singer et al., 1991; Striessnig et al., 1998). And these regions are encoded by exon 24, 25, 26, 27, 34, 35 and 36 (Hering et al., 1998).

The primary purpose of this study is to identify the correlation between ADRs produced by CCBs and SNPs of relevant gene. Here we determined specific exons encoding 1,4-DHP binding site in the CACNA1C gene. In addition, we analyzed the exon 8 that is known to have various SNPs.

\section{MATERIALS AND METHODS}

\section{Study population}

In order to identify the effect of the polymorphism of CACNA1C gene on ADRs of CCBs, a case-control study was conducted from June 2004 to November 2004 in Asan Medical
Center (Seoul, Korea). The case was defined as hypertensive patient with adverse reactions against $\mathrm{CCBs}$. Among $\mathrm{CCBs}$, Amlodipine were used for most study subjects (60\% and $63 \%$, respectively in the case and control group) and Cilnidipine were taken in $25 \%$ and $29 \%$ of the case or control subjects. And small number of patients (7 and 4, each of group) were taking other CCBs, such as nifedipine, lercanidipine hydrochloride, felodipine, and diltiazem hydrochloride. Although the study subjects were not taking the same CCB, the proportional distribition of using drug in each group were similar. Thus, it doesn't look like having significant impact on the occurrence of ADR between groups. The recruited cases were from hypertension cohort established from Asan Medical Center in 1999 and 2002. During the research period, 48 cases and 52 controls were enrolled, at the beginning, but one of the case group and three of the control group were not available for genetic analysis. Demographic information, adverse reaction, and blood pressure control were checked using questionnaire and medical chart. Written informed consent approved by the ethics committee of Asan Medical Center was obtained from each subject for participation in this study. Blood was drawn into an EDTA-treated tube and kept in refrigeration and DNA was isolated within 72 hours.

\section{Genomic DNA Isolation}

The buffy coat was obtained from whole blood using Histopaque-1077 (Sigma). Then we extracted genomic DNA using a DNA purification Kit (Promega). The isolated DNA was diluted in DNA rehydration solution (Promega) and stored at $-20^{\circ} \mathrm{C}$ before using.

\section{PCR or DNA Amplification}

The primers for Polymerase Chain Reaction were presented in Table I. These primers to amplify specific exons of CACNA1C gene were designed from primer 3 website (http:// frodo.wi.mit.edu/cgi-bin/primer3/primer3_www.cgi).

Each $20 \mu \mathrm{l}$ PCR reaction contained $20 \mathrm{ng}$ of genomic DNA, $0.25 \mu \mathrm{M}$ of forward/reverse primer, $10 \mathrm{mM}$ of each dNTP mixture (Applied Biosystem), $2 \mu \mathrm{l}$ of reaction PCR buffer with 1.5 $\mathrm{mM} \mathrm{MgCl} 2$ and 1 unit of AmpliTaq ${ }^{\circledR}$ Gold (Applied Biosystem). PCR was performed at 94 for 2 minutes, followed by 35 cycles at $94^{\circ} \mathrm{C}$ for 10 seconds, $55 \sim 60$ for 30 seconds, $72^{\circ} \mathrm{C}$ for 90 seconds, and final extension at $72^{\circ} \mathrm{C}$ for 5 minutes. PCR products were confirmed by electrophoresis in $2 \%$ agarose gel (Bioneer) stained with ethidium bromide (Nalgene).

\section{DNA Sequencing}


Table I. The Primer for PCR amplification

\begin{tabular}{|c|c|c|c|c|c|c|c|}
\hline Exon & & Primer Sequence & size (b.p) & Exon & & Primer Sequence & size (b.p.) \\
\hline \multirow{2}{*}{8} & $\mathrm{~F}$ & cct ctg ttc aac cac aga tt & \multirow{2}{*}{359} & \multirow{2}{*}{27} & $\mathrm{~F}$ & cca agg tca cac agc cag ta & \multirow{2}{*}{467} \\
\hline & $\mathrm{R}$ & ata cag cca gg aat agc aga & & & $\mathrm{R}$ & cag tat ctg cac ggc ctc tc & \\
\hline \multirow{2}{*}{24} & $\mathrm{~F}$ & ccc ctc tca gcc caa tta ct & \multirow{2}{*}{388} & \multirow{2}{*}{34} & $\mathrm{~F}$ & ggt tgc atg gga aga ctg tt & \multirow{2}{*}{309} \\
\hline & $\mathrm{R}$ & ccc tac cet ggt ctg aag gt & & & $\mathrm{R}$ & att cta cca cca ggc cac ag & \\
\hline \multirow{2}{*}{25} & $\mathrm{~F}$ & agt gct ggg cta tgg aga tg & \multirow{2}{*}{334} & \multirow{2}{*}{35} & $\mathrm{~F}$ & gta act ccc tct ggg gaa gg & \multirow{2}{*}{379} \\
\hline & $\mathrm{R}$ & gag ctt cag tgg gca gaa ac & & & $\mathrm{R}$ & tct gat agg gtt gcc ctg ac & \\
\hline \multirow{2}{*}{26} & $\mathrm{~F}$ & gaa gtt caa gcc agg cag tc & \multirow{2}{*}{385} & \multirow{2}{*}{36} & $\mathrm{~F}$ & cag gtt ctc agg ctg gta gg & \multirow{2}{*}{375} \\
\hline & $\mathrm{R}$ & ggg gag gac cca ggt aaa ta & & & $\mathrm{R}$ & att gat cca ccc agt gtt gg & \\
\hline
\end{tabular}

After individual PCR products displayed a clear single band, PCR products were purified and then sequenced. The proper amount of sample according to the size of PCR fragment was taken for sequencing PCR. The total reaction volume for sequencing was $10 \mu \mathrm{l}$ in a mixture containing $1 \mu \mathrm{l}$ of PCR products $(10 \mathrm{ng} / 1 \mu \mathrm{l}), 2 \mu \mathrm{l}$ of Bigdye ${ }^{\circledR}$ (Terminator 3.0 cycle sequencing kit, Applied Biosytem), $1.5 \mu \mathrm{M}$ of forward or reverse primer. Cycle conditions for sequencing PCR were 1 minute at $96^{\circ} \mathrm{C}$ for denaturation, 5 seconds at $57^{\circ} \mathrm{C}$ for annealing, 1 minute at $60^{\circ} \mathrm{C}$ for elongation for 25 cycles. The products of sequencing PCR were purified using ethanol (Sigma). Then, $10 \mu \mathrm{l}$ of Hi-Di formamide ${ }^{\circledR}$ (Applied Biosystem) were added and denatured at $95^{\circ} \mathrm{C}$ for 2 minutes. Sequencing was performed using ABI Avant 3100 DNA Sequencer programmed by BigDye Terminator 3.0 cycle sequencing kit standard (Applied Biosytem).

\section{Detection of SNPs by direct sequencing}

The samples were sequenced with BigDye terminator v3.0 cycle sequencing Kit on the ABI Avant 3100 DNA sequencer. Sequences were analyzed by Lasergene software (DNAStar, Madison, WI).

\section{Statistical Analysis}

Statistical analysis was performed by HapAnalyzer. This software consists of the following minimum analysis components; Hardy-Weinberg equilibrium (HWE) Test, SNP (or haplotype)-phenotype association, and linkage disequilibrium (LD) test. This software is available from National Geonome Research Institute (http://hap.ngri.re.kr/).

\section{RESULTS}

\section{The baseline clinical characteristics for the patients}

The baseline clinical characteristics in 100 patients are shown in Table II. BMI and duration of administration in case group are significantly different from control. However, means of age, systolic BP, diastolic BP, kinds of CCBs, smoking and medication didn't show significant differences between case and control. Although three patients of the control group and one of the case group were not available for genetic analysis, they didn't make any difference in the comparison of clinical profiles between groups.

\section{Adverse drug reaction by Ca channel blocker}

Table III showed the frequency of adverse reaction followed by each CCB. Multiple answers of ADRs were allowed. As shown in the table III, the most frequent ADRs were edema of lower limb in Amlodipine and flush in Cilnidipine. However, Kim et al. (2000) reported that headache was the most common ADR, followed by flushing and edema. These results may be due to the difference in the age of study subjects, since they enrolled relatively younger patients than those in our study and patients has been reported one of factors to affect the incidence

Table II. Baseline characteristics of 100 patients

\begin{tabular}{|c|c|c|c|c|c|}
\hline & \multicolumn{2}{|c|}{$\begin{array}{c}\text { Case } \\
(\mathrm{n}=48)\end{array}$} & \multicolumn{2}{|c|}{$\begin{array}{c}\text { Control } \\
(\mathrm{n}=52)\end{array}$} & p-value \\
\hline$\overline{\text { Age (years) }}$ & \multicolumn{2}{|c|}{$61.9 \pm 9.3$} & \multicolumn{2}{|c|}{$64.0 \pm 9.6$} & \\
\hline $\mathrm{BMI}\left(\mathrm{kg} / \mathrm{m}^{2}\right)$ & \multicolumn{2}{|c|}{$25.0 \pm 2.6$} & \multicolumn{2}{|c|}{$26.3 \pm 2.5$} & $<.01$ \\
\hline Systolic BP (mmHg) & \multicolumn{4}{|c|}{$137.8 \pm 17.9136 .3 \pm 18.1$} & \\
\hline Diastolic BP (mmHg) & \multicolumn{2}{|c|}{$81.5 \pm 12.7$} & \multicolumn{2}{|c|}{$83.0 \pm 9.3$} & \\
\hline \multicolumn{6}{|l|}{ CCB drugs } \\
\hline Amlodipine & 29 & $60 \%$ & 33 & $63 \%$ & \\
\hline Cilnidipine & 12 & $25 \%$ & 15 & $29 \%$ & \\
\hline Others & 7 & $15 \%$ & 4 & $8 \%$ & \\
\hline Duration of administration (months) & 64.5 & \pm 10.6 & 67.4 & \pm 8.9 & $<.05$ \\
\hline \multicolumn{6}{|l|}{ Smoking } \\
\hline Never & 33 & $69 \%$ & 40 & $77 \%$ & \\
\hline Ever & 13 & $27 \%$ & 6 & $12 \%$ & \\
\hline Current & 2 & $4 \%$ & 6 & $12 \%$ & \\
\hline \multicolumn{6}{|l|}{ Medication } \\
\hline antihypertensive drug & 47 & $98 \%$ & 51 & $98 \%$ & \\
\hline non & 1 & $2 \%$ & 1 & $2 \%$ & \\
\hline
\end{tabular}


Table III. Adverse reactions against CCBs in hypertensive patients

\begin{tabular}{|c|c|c|c|c|c|c|c|c|}
\hline & \multicolumn{2}{|c|}{ Amlodipine $(n=29)$} & \multicolumn{2}{|c|}{ Cilnidipine $(\mathrm{n}=12)$} & \multicolumn{2}{|c|}{ Others $(n=7)$} & \multicolumn{2}{|c|}{ Total $(n=48)$} \\
\hline & $\mathrm{n}$ & $(\%)$ & $n$ & $(\%)$ & $\mathrm{n}$ & $(\%)$ & $\mathrm{n}$ & $(\%)$ \\
\hline edema (lower limb) & 14 & $(48 \%)$ & 4 & $(33 \%)$ & 2 & $(29 \%)$ & 20 & $(42 \%)$ \\
\hline flush & 8 & $(28 \%)$ & 5 & $(42 \%)$ & 1 & $(14 \%)$ & 14 & $(29 \%)$ \\
\hline headache & 4 & $(14 \%)$ & 3 & $(25 \%)$ & 2 & $(29 \%)$ & 9 & $(19 \%)$ \\
\hline edema (other) & 5 & $(17 \%)$ & 4 & $(33 \%)$ & 0 & $(0 \%)$ & 9 & $(19 \%)$ \\
\hline gingival hyperplastica & 6 & $(21 \%)$ & 0 & $(0 \%)$ & 0 & $(0 \%)$ & 6 & $(13 \%)$ \\
\hline palpitation & 1 & $(3 \%)$ & 2 & $(17 \%)$ & 2 & $(29 \%)$ & 5 & $(10 \%)$ \\
\hline dizziness & 2 & $(7 \%)$ & 0 & $(0 \%)$ & 1 & $(14 \%)$ & 3 & $(6 \%)$ \\
\hline infirmity & 0 & $(0 \%)$ & 1 & $(8 \%)$ & 1 & $(14 \%)$ & 2 & $(4 \%)$ \\
\hline pruritus & 1 & $(3 \%)$ & 0 & $(0 \%)$ & 0 & $(0 \%)$ & 1 & $(2 \%)$ \\
\hline chest discomfort & 1 & $(3 \%)$ & 0 & $(0 \%)$ & 0 & $(0 \%)$ & 1 & $(2 \%)$ \\
\hline abdominal distention & 1 & $(3 \%)$ & 0 & $(0 \%)$ & 0 & $(0 \%)$ & 1 & $(2 \%)$ \\
\hline
\end{tabular}

of ADRs (Aellig, 1998).

\section{DISCUSSION}

\section{Sequencing Results}

The overall genotype distribution of the CACNA1C gene was in Hardy-weinberg equilibrium. Because common ADRs such as edema and flush induced by CCBs could be resulted from the excessive vessel dilation, we investigated the L-type calcium channel containing the binding site of 1,4-DHP.

L-Type calcium channel is a complex of the main, poreforming subunit alpha-1 and four additional subunits: alpha-2, delta, beta and gamma (Uneyama et al., 1997). Among the subtype of alpha-1, 1,4-DHP binds to the alpha 1C subunits (CACNA1C) with high affinity (Birnbaumer et al., 1994; Hofmann et al., 1994). Thus, we expected that some SNPs in this gene might be involving ADRs. However, There was no SNP within exons encoding the binding regions of 1,4-DHPs in this study. In stead, we found four novel SNPs in the flanking regions of Exon 24, 25, and 36 and we analyzed their association with the presence of ADRs in each groups as shown in Table IV. And we couldn't find out any SNPs in exon 8. These results suggest that there was no relationship between the SNP encoding the binding site of 1,4-DHPs and ADRs from 1,4DHPs in Korean.
The person-to-person variability of drug response is a major problem in clinical practice (Meyer, 2000). It can lead to adverse drug reactions in individual or subpopulations of patients (Meyer, 2000). Recently, it has become clear that the genetic polymorphism may significantly modify drug responses or increase the risk for ADRs (Pirmohamed and Park, 2001; Schmitz et al., 2001). Many researchers are trying to find valid genetic biomarkers to predict the efficacy or toxicity of drug. Therefore, SNPs can be very useful genetic biomarkers to identify the association of ADR with relevant or susceptible genes (Lee et al., 2003). Actually, the studies on pharmacogenomics have become an essential work frame and have significant influences on drug development (Ginsburg et al., 2005; Guo et al., 2005).

Through retrospective pharmacogenomic studies, many patients can be protected from ADRs. For examples, drugs metabolized by CYP2D6 such as haloperidol and codeine vary from increased risk of ADRs at recommended doses in poor metabolizers (Linder et al., 1997). Genetic variants of CYP2C19 enzyme may cause differences in metabolism of omeprazole. Polymorphisms of thiopurine S-methyltransferase

Table IV. The detected SNPs in the CACNA1C gene ( $\mathrm{N}=96)$

\begin{tabular}{|c|c|c|c|c|c|c|c|}
\hline \multirow{3}{*}{ SNP location } & \multirow{2}{*}{ Group } & \multicolumn{3}{|c|}{ Control $(\mathrm{N}=49)$} & \multicolumn{3}{|c|}{ Case $(\mathrm{N}=47)$} \\
\hline & & $\mathrm{w} / \mathrm{w}$ & $\mathrm{w} / \mathrm{m}$ & $\mathrm{m} / \mathrm{m}$ & $\mathrm{w} / \mathrm{w}$ & $\mathrm{w} / \mathrm{m}$ & $\mathrm{m} / \mathrm{m}$ \\
\hline & \multirow{2}{*}{$\begin{array}{l}\text { Variation } \\
\mathrm{C}>\mathrm{T}\end{array}$} & & $\mathrm{N}(\%)$ & & \multicolumn{3}{|c|}{$\mathrm{N}(\%)$} \\
\hline IVS24+85C/T & & $48(98)$ & $1(2)$ & $0(0)$ & $47(100)$ & $0(0)$ & $0(0)$ \\
\hline IVS25+139T/C & $\mathrm{T}>\mathrm{C}$ & $20(41)$ & $19(39)$ & $10(20)$ & $17(36)$ & $23(49)$ & $7(15)$ \\
\hline IVS35-80C/A & $\mathrm{C}>\mathrm{A}$ & $5(10)$ & $13(27)$ & $31(63)$ & $5(11)$ & $12(25)$ & $30(64)$ \\
\hline IVS36+47G/A & $\mathrm{G}>\mathrm{A}$ & 47 (96) & $2(4)$ & $0(0)$ & $46(98)$ & $1(2)$ & $0(0)$ \\
\hline
\end{tabular}


reduce biotransformation of thiopurine drugs such as azathioprine, and 6-mercaptopurin can lead to potentially fetal hematopoietic toxicity in some patients (Relling et al., 1999).

Until now, pharmacogenetic study is somewhat limited in the research for the relationship of pharmacokinetic parameter and genetic polymorphism. Although many researchers have tried to elucidate the correlation between SNPs and ADRs, there is a little evidence less than we expected. It is assumed that adverse drug events are not caused by simple biological mechanism which involves abnormal gene expression failure (Licinio and Wong, 2002). In this study, we wanted to find useful information for hypertensive patients who have experienced adverse drug reaction with $\mathrm{CCBs}$, since $\mathrm{CCBs}$ were one of the most commonly prescribed antihypertensive agents in Korea (Kim et al., 2000). It also has been reported that the incidences of ADRs associated with antihypertensive agents were different by race, age and drug class (Aellig, 1998). Thus, we evaluated baseline characteristics of study subjects to exclude any possibility of differences coming from their characteristics (Table II). And we confirmed that their age or the proportion of prescribing drugs class were not different between the case and the control group. Here we investigated a correlation between SNPs of CACNA1C, calcium channel encoding gene and CCB's adverse reactions.

CYP3A4, a metabolizing enzyme for most calcium channel antagonist can be a potential candidate gene. Because genetic variants of metabolic enzymes such as CYP2D6, CYP2C19 and $\mathrm{CYP} 2 \mathrm{C} 9$ have been known to affect the activity of these enzymes, and to be responsible for most ADRs demonstrated (Nelson et al., 1996), metabolic enzymes can be proper targets to identify the cause of adverse reactions (Dalen et al., 2003; Koytchev et al., 1998). However, few functional polymorphisms are known for the CYP3A4, and CYP3A4 activity is highly variable among patients even in the absence of known mutations (Nakagawa and Ishizaki, 2000; Phillips et al., 2001; Severino and Del Zompo, 2004; Torpet et al., 2004). Therefore, we focused on the CACNA1C gene encoding the binding site of cacium channel antagonist.

Although we couldn't find SNPs in the investigated exons, we found four novel SNPs in the exon-intron junction region. It is known that SNPs which associate directly with phenotype usually exist within the exon. However, SNPs to exist intronic gene regions may have a significant role because these SNPs can provide an important clue through linkage disequilibrium (LD) and they also have functional consequences. In addition, it also has been known that SNPs that lie close to intron-exon boundaries can affect the gene splicing or the gene expression. Actually, splicing-site mutations in the SURF1 gene result in loss of SURF1 protein and develop Lei syndrome (Pequignot et al., 2001). And intronic sequences in BRACA1 gene have been demonstrated to have transcriptional repressor activity (Suen and Goss, 2001). Herein, we couldn't demonstrate any association between SNPs we found and the occurrence of ADRs. However, it still needs to be further investigated whether novel SNPs has any functional change of gene activity by in vitro transcriptional study.

Although several studies have reported that genes encoding calcium channel have diverse genetic polymorphism, there have been no reports regarding associations between SNP in gene encoding calcium channel and ADRs from CCBs. One study reported that several SNPs in exonal regions has been associated with the efficacy of antihypertensive agents. Thus, ADRs or efficacy from antihypertensive agents might be clearly associated with several known SNPs on exons based on previous studies. And in this study, we couldn't find previously known SNPs on exons in Korean and this might be the reason we couldn't find any association. In conclusion, our results suggest that other novel SNPs on flanking regions in Korean were not associated with adverse reaction caused by CCBs, even if it still need to be required to explore in more depth by further detailed study.

\section{REFERENCE}

Aellig, W. H. (1998). Adverse reactions to antihypertensive therapy. Cardiovasc Drugs Ther 18(Suppl.): 55-58.

Barone, F. C., Feuerstein, G. Z. and Spera, R. P. (1997). Calcium channel blockers in cerebral ischaemia. Expert Opin Investig Drugs 6, 501-519.

Birnbaumer, L., Campbell, K. P., Catterall, W. A., Harpold, M. M., Hofmann, F., Horne, W. A., Mori, Y., Schwartz, A., Snutch, T. P. and Tanabe, T. (1994). The naming of voltagegated calcium channels. Neuron 13, 505-506.

Dalen, P., Dahl, M. L., Roh, H. K., Tybring, G., Eichelbaum, M., Wilkinson, G. R. and Bertilsson, L. (2003). Disposition of debrisoquine and nortriptyline in Korean subjects in relation to CYP2D6 genotypes, and comparison with Caucasians. Br. J. Clin. Pharmacol. 55, 630-634.

De Leeuw, P.W. and Birkenhager, W. H. (2002). The effects of calcium channel blockers on cardiovascular outcomes: a review of randomised controlled trials. Blood Press 11, 71-78.

Ertel, E. A., Campbell, K. P., Harpold, M. M., Hofmann, F., Mori, Y., Perez-Reyes, E., Schwartz, A., Snutch, T. P., Tanabe, T. and Birnbaumer, L. (2000). Nomenclature of voltage-gated calcium channels. Neuron 25, 533-535.

Furukawa, T., Nukada, T., Suzuki, K., Fujita, Y., Mori, Y., Nishimura, M. and Yamanaka, M. (1997). Voltage and pH dependent block of cloned N-type $\mathrm{Ca} 2+$ channels by amlodipine. $\mathrm{Br}$. 
J. Pharmacol 121, 1136-1140.

Ginsburg, G. S., Konstance, R. P., Allsbrook, J. S. and Schulman, K.A. Implications of pharmacogenomics for drug development and clinical practice. Arch. Intern. Med. (2005). 165, 2331-2336.

Guo, Y., Shafer, S., Weller, P., Usuka, J. and Peltz, G. (2005). Pharmacogenomics and drug development. Pharmacogenomics 6, 857-864.

Hering, S., Berjukow, S., Aczel, S. and Timin, E.N. (1998). $\mathrm{Ca}^{2+}$ channel block and inactivation: common molecular determinants. Trends Pharmacol Sci 19, 439-443.

Hockerman, G. H., Peterson, B. Z., Johnson, B. D. and Catterall, W. A. (1997). Molecular determinants of drug binding and action on L-type calcium channels. Annu. Rev. Pharmacol. Toxicol. 37, 361-396.

Hofmann, F., Biel, M. and Flockerzi, V. (1994). Molecular basis for $\mathrm{Ca}^{2+}$ channel diversity. Annu. Rev. Neurosci. 17, 399-418.

Kim, Y. S., Park, H. S., Sunwoo, S., Byeon, J. J., Song, Y. M., Seo, H. G., Kim, C. H., Cheon, K. S., Yoo, S. M. and Lee, J. K. (2000). Short-term safety and tolerability of antihypertensive agents in Korean patients: an observational study. Pharmacoepidemiol. Drug Saf. 9, 603-609.

Koytchev, R., Alken, R. G., Vlahov, V., Kirkov, V., Kaneva, R., Thyroff-Friesinger, U. and Rehak, E. (1998). Influence of the cytochrome P4502D6*4 allele on the pharmacokinetics of controlled-release metoprolol. Eur. J. Clin. Pharmacol. 54, 469474.

Lee, J. K., Kim, H. T., Cho, S. M., Kim, K. H., Jin, H. J., Ryu, G. M., Oh, B., Park, C., Kimm, K. and Jo, S. A. (2003). Characterization of 458 single nucleotide polymorphisms of disease candidate genes in the Korean population. J. Hum. Genet. 48 213-216.

Lesko, L. J. and Woodcock, J. (2004). Translation of pharmacogenomics and pharmacogenetics: a regulatory perspective. Nat. Rev. Drug. Discov. 3, 763-769.

Licinio, J. and Wong, M. -L. (2002). Pharmacogenomics : the search for individualized therapies Weinheim, Wiley-VCH.

Linder, M. W., Prough, R. A. and Valdes, R. (1997). Jr. Pharmacogenetics: a laboratory tool for optimizing therapeutic efficiency. Clin. Chem. 43, 254-266.

Little, S. (2005). The impact of FDA guidance on pharmacogenomic data submissions on drug development. IDrugs 8, 648650.

Liu, L., Fan, Q. I., El-Zaru, M. R., Vanderpool, K., Hines, R. N. and Marsh, J. D. (2000). Regulation of DHP receptor expression by elements in the 5 '-flanking sequence. Am. J. Physiol Heart. Circ. Physiol. 278, H1153-1162.

Mango, R., Vecchione, L., Raso, B., Borgiani, P., Brunetti, E., Mehta, J. L., Lauro, R., Romeo, F. and Novelli, G. (2005). Pharmacogenomics in cardiovascular disease: the role of single nucleotide polymorphisms in improving drug therapy. Expert Opin. Pharmacother. 6, 2565-2576.

Marsh, S., and McLeod, H. L. (2006). Pharmacogenomics: from bedside to clinical practice. Hum. Mol. Genet. 15 Spec No 1, R89-93.

Mason, R. P., Marche, P. and Hintze, T. H. (2003). Novel vascular biology of third-generation L-type calcium channel antagonists: ancillary actions of amlodipine. Arterioscler. Thromb. Vasc. Biol. 23, 2155-2163.
Meyer, U. A. (2000). Pharmacogenetics and adverse drug reactions. Lancet 356, 1667-1671.

Muntwyler, J. and Follath, F. (2001). Calcium channel blockers in treatment of hypertension. Prog. Cardiovasc. Dis. 44, 207-216.

Nakagawa, K. and Ishizaki, T. (2000). Therapeutic relevance of pharmacogenetic factors in cardiovascular medicine. Pharmacol. Ther. 86, 1-28.

Nelson, D. R., Koymans, L., Kamataki, T., Stegeman, J. J., Feyereisen, R., Waxman, D.J., Waterman, M. R., Gotoh, O., Coon, M. J. and Estabrook, R. W. (1996). P450 superfamily: update on new sequences, gene mapping, accession numbers and nomenclature. Pharmacogenetics 6, 1-42.

Pequignot, M. O., Desguerre, I., Dey, R., Tartari, M., Zeviani, M., Agostino, A., Benelli, C., Fouque, F., Prip-Buus, C. and Marchant, D. (2001). New splicing-site mutations in the SURF1 gene in Leigh syndrome patients. J. Biol. Chem. 276, 15326-15329.

Phillips, K. A., Veenstra, D. L., Oren, E., Lee, J. K. and Sadee, W. (2001). Potential role of pharmacogenomics in reducing adverse drug reactions: a systematic review. J.A.M.A. 286, 2270-2279.

Pirmohamed, M. and Park, B. K. Genetic susceptibility to adverse drug reactions. Trends Pharmacol. Sci. 22, 298-305. (2001).

Regulla, S., Schneider, T., Nastainczyk, W., Meyer, H. E. and Hofmann, F. (1991). Identification of the site of interaction of the dihydropyridine channel blockers nitrendipine and azidopine with the calcium-channel alpha 1 subunit. Embo. J. 10, 4549.

Relling, M. V., Hancock, M. L., Rivera, G. K., Sandlund, J. T., Ribeiro, R. C., Krynetski, E. Y., Pui, C. H. and Evans, W. E. (1999). Mercaptopurine therapy intolerance and heterozygosity at the thiopurine S-methyltransferase gene locus. J. Natl. Cancer. Inst. 91, 2001-2008.

Schmitz, G., Aslanidis, C. and Lackner, K. J. (2001). Pharmacogenomics: implications for laboratory medicine. Clin. Chim. Acta. 308, 43-53.

Severino, G. and Del Zompo, M. (2004). Adverse drug reactions: role of pharmacogenomics. Pharmacol. Res. 49, 363-373.

Singer, D., Biel, M., Lotan, I., Flockerzi, V., Hofmann, F. and Dascal, N. (1991). The roles of the subunits in the function of the calcium channel. Science 253, 1553-1557.

Solus, J. F., Arietta, B. J., Harris, J. R., Sexton, D. P., Steward, J. Q., McMunn, C., Ihrie, P., Mehall, J. M., Edwards, T. L. and Dawson, E. P. (2004). Genetic variation in eleven phase I drug metabolism genes in an ethnically diverse population. Pharmacogenomics 5, 895-931.

Striessnig, J., Grabner, M., Mitterdorfer, J., Hering, S., Sinnegger, M. J. and Glossmann, H. (1998). Structural basis of drug binding to $\mathrm{L} \mathrm{Ca}^{2+}$ channels. Trends Pharmacol Sci 19, 108-115.

Suen, T. C. and Goss, P. E. (2001). Identification of a novel transcriptional repressor element located in the first intron of the human BRCA1 gene. Oncogene 20, 440-450.

Torpet, L.A., Kragelund, C., Reibel, J. and Nauntofte, B. (2004). Oral Adverse Drug Reactions to Cardiovascular Drugs. Crit Rev Oral. Biol. Med. 15, 28-46.

Uneyama, H., Takahara, A., Dohmoto, H., Yoshimoto, R., Inoue, K. and Akaike, N. (1997). Blockade of N-type Ca2+ current by cilnidipine (FRC-8653) in acutely dissociated rat sympathetic neurones. Br. J. Pharmacol. 122, 37-42. 